\title{
Self-reported musculoskeletal disorders by the nursing team in a university hospital
}

\author{
Distúrbios musculoesqueléticos autorreferidos na equipe de enfermagem em um hospital \\ universitário
}

Edilson Gonçalves Maciel Júnior ${ }^{1}$, Francis Trombini-Souza², Paula Adreatta Maduro ${ }^{3}$, Fabrício Olinda Souza Mesquita ${ }^{3}$, Tarcísio Fulgêncio Alves da Silva²

\section{ABSTRACT}

BACKGROUND AND OBJECTIVES: The hospital environment is considered to be unhealthy, and, moreover, the work performed by nursing professionals presents several risk factors for the development of pain. In this sense, the present study aims to analyze the musculoskeletal disorders in the nursing team and to correlate with the level of physical activity, anthropometric characteristics and the professional profile at the University Hospital in Petrolina, Pernambuco.

METHODS: This was a cross-sectional study with 143 nursing professionals, of which 122 were female (37 \pm 7 years) and 21 were male ( $33 \pm 6$ years). The individuals answered the International Physical Activity Questionnaire and the Nordic Musculoskeletal Questionnaire.

RESULTS: Pain was reported in 77 volunteers, which corresponds to $53.8 \%$ of the sample. In $35(24.4 \%)$ volunteers there was the presence of musculoskeletal disorders in more than one body segment. Regarding pain distribution by body segment, the higher prevalence's were observed in the lumbar region and the knees, both with $17.4 \%$. In addition, there were associations between being male and pain in the elbows ( $\mathrm{PR}=5.5,95 \% \mathrm{CI}: 1.1,25.5, \mathrm{p}=0.028)$ and ankles (PR=5.1, 95\% CI: 1.3; 19.2, $\mathrm{p}=0.016)$, and pain and physical inactivity for the elbow segments $(\mathrm{PR}=3.4,95 \% \mathrm{CI}: 1.1$, 10.3, $\mathrm{p}=0.027)$ and knees ( $\mathrm{PR}=2.4,95 \% \mathrm{CI}: 1.1,5.0, \mathrm{p}=0.021)$.

CONCLUSION: It can be noticed that the prevalence of pain in the team of professionals analyzed was high and that the risk

\footnotetext{
Edilson Gonçalves Maciel Júnior - (1)https://orcid.org/0000-0001-6290-373X;

Francis Trombini-Souza - Dhttps://orcid.org/0000-0001-8862-4691;

Paula Adreatta Maduro - (Dhttps://orcid.org/0000-0003-2174-2460;

Fabrício Olinda Souza Mesquita - Dhttps://orcid.org/0000-0001-7514-2757;

Tarcísio Fulgêncio Alves da Silva - (Dhttps://orcid.org/0000-0001-5982-9954.

1. Universidade de Pernambuco, Faculdade de Fisioterapia, Petrolina, PE, Brasil.

2. Universidade de Pernambuco, Petrolina, PE, Brasil.

3. Universidade Federal do Vale do São Francisco, Hospital Universitário, Empresa Brasileira de Serviços Hospitalares, Petrolina, PE, Brasil.

Submitted on October 22, 2018.

Accepted for publication on March 21, 2019.

Conflict of interests: none - Sponsoring sources: none.

Correspondence to:

Rodovia BR 203, Km 02, s/n - Vila Eduardo

56328-903 Petrolina, PE, Brasil.

E-mail: tarcisio.silva@upe.br

(C) Sociedade Brasileira para o Estudo da Dor
}

factors, such as physical inactivity and being male were associated with a greater onset of musculoskeletal disorders.

Keywords: Cumulative trauma disorders, Occupational health, Pain.

\section{RESUMO}

JUSTIFICATIVA E OBJETIVOS: O ambiente hospitalar é considerado como insalubre, além disso, a atividade laboral desempenhada pelos profissionais de enfermagem apresenta diversos fatores de risco para o desenvolvimento de dor. Nesse sentido, o presente estudo teve por objetivo analisar os distúrbios musculoesqueléticos na equipe de enfermagem e correlacionar com o nível de atividade física, características antropométricas e o perfil profissional no Hospital Universitário em Petrolina, Pernambuco.

MÉTODOS: Trata-se de um estudo transversal, com 143 profissionais de enfermagem, sendo 122 do sexo feminino ( $37 \pm 7$ anos) e 21 do sexo masculino ( $33 \pm 6$ anos). Os indivíduos responderam aos questionários Internacional de Atividade Física e ao Nórdico de Sintomas Osteomusculares.

RESULTADOS: Foi constatada a presença de dor em 77 voluntários, o que equivale a 53,8\% da amostra. Em 35 (24,4\%) voluntários houve a presença de distúrbios musculoesqueléticos em mais de um segmento corporal. Quanto à distribuição de dor por segmento corporal, foram observadas maiores prevalências na região lombar e nos joelhos, ambas com 17,4\%. Além disso, foram verificadas associaçóes entre o sexo masculino e dor nos cotovelos $(\mathrm{RP}=5,5, \mathrm{IC} 95 \%: 1,1 ; 25,5, \mathrm{p}=0,028)$ e tornozelos $(\mathrm{RP}=5,1$, IC 95\%:1,3;19,2, $\mathrm{p}=0,016)$, e dor e inatividade física para os segmentos em cotovelos ( $\mathrm{RP}=3,4$, IC 95\%:1,1;10,3, $\mathrm{p}=0,027)$ e joelhos ( $\mathrm{RP}=2,4$, IC95\%: 1,1; 5,0, $\mathrm{p}=0,021)$.

CONCLUSÁO: Observou-se que a prevalência de dor na equipe de profissionais analisada foi elevada, e que fatores de risco como a inatividade física e o sexo masculino, foram associados com maior surgimento dos distúrbios musculoesqueléticos.

Descritores: Dor, Saúde do Trabalhador, Transtornos traumáticos cumulativos.

\section{INTRODUCTION}

Work-related musculoskeletal disorders (WRMD) are disarrangements that affect the muscle structures, tendons, synovial membranes, nerves, fascia, and ligaments, in a combined or isolated form, with or without the degeneration of work-related 
tissues. Currently, the literature adopts the term musculoskeletal disorders (MSD) in place of the WRMD expression ${ }^{1}$.

MSD is becoming a relevant problem for public health, especially in industrialized countries, affecting workers in different sectors because they determine a variety of signs and symptoms, such as pain, discomfort, the feeling of weight, fatigue, paresthesia, movement limitation, among others, that may be concurrent or not. Generally, they start insidiously and evolve rapidly if there are no changes in the working conditions ${ }^{1,2}$.

In this sense, it is possible to say that the workspace presents several risk factors for the onset of MSD, mainly due to the association between inadequate work environment and the poor physical conditions of the workers. The hospital environment can generate emotional stress and physical injuries due to its unhealthy nature with continuous exposure to one or more factors that can lead to diseases or illness resulting from the very nature of the work and its organization ${ }^{1,3}$.

Among health professionals, the nursing staff has a high incidence and prevalence of $\mathrm{MSD}^{4,5}$, due to the demanding hospital environment. Generally, the activities performed by these workers are directly related to the patient and may require inappropriate postures; work overload; weightlifting; repetitive movements and tension in addition to factors such as poor work organization; inadequate equipment and excessive demand for productivity ${ }^{6}$.

The objective of this study was to analyze MSD in the nursing team and to correlate with the level of physical activity (PA), anthropometric characteristics and the professional profile at the University Hospital (UH) of Petrolina, Pernambuco.

\section{METHODS}

This is a cross-sectional study. The analyzed population comprises professional nurses, and nursing technicians' employees of the Federal University Vale do São Francisco (UNIVASF), in the city of Petrolina, Pernambuco. All were invited to participate, and the research was carried out with a convenience sample of 143 nursing professionals. The inclusion criteria were a minimum age of 18 years; the presence of employment relationship with at least one month in the UH. The exclusion criteria were all subjects who did not meet the requirements described or who did not agree to participate in the research. Demographic and anthropometric data were collected, such as gender, age, mass, and height. In addition, two evaluation tools were applied, the Nordic Musculoskeletal Questionnaire (NMQ), and the International Physical Activity Questionnaire (IPAQ).

The NMQ was used in its general form that comprises all the anatomical area for the evaluation of the major symptoms of MSD.

This instrument was validated in Brazil in $2002^{7}$ and consists of multiple or binary choices regarding the occurrence of symptoms in several anatomical regions in which they are more common, according to figure 1 . The pain referred to in the last seven days was considered for analysis in this study.

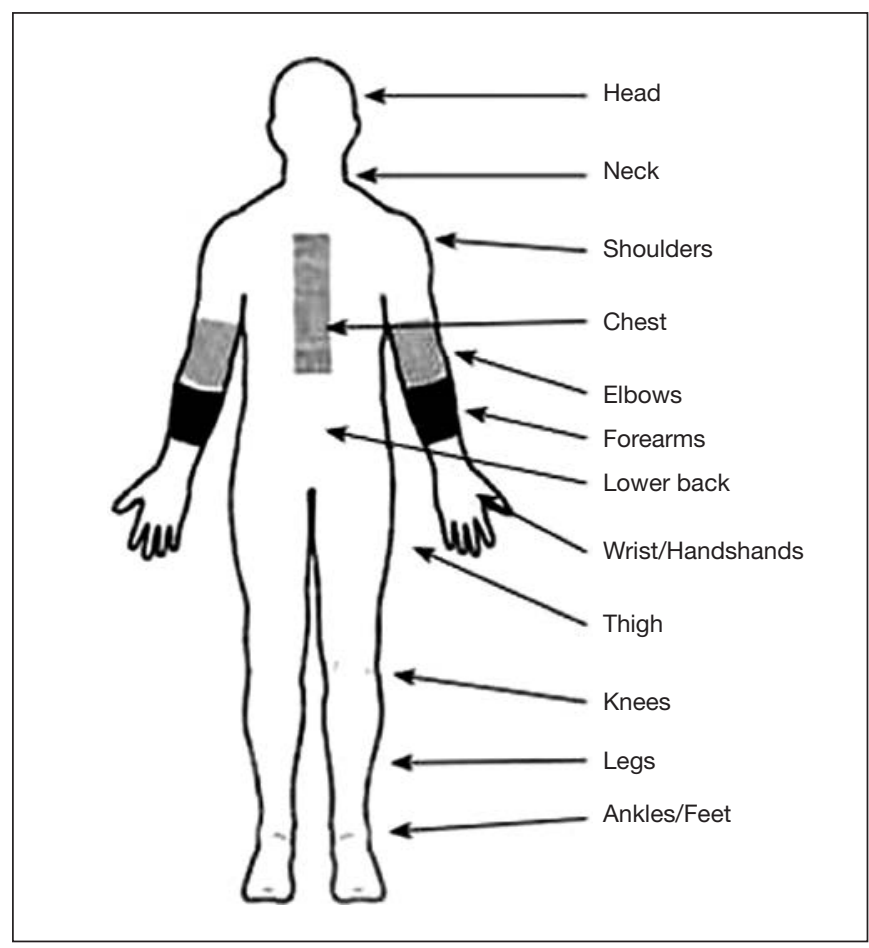

Figure 1. Anatomic regions investigated by the Nordic Musculoskeletal Questionnaire ${ }^{8}$

Another important factor in evaluating workers is the Physical Activity Index by IPAQ since the more physically inactive the individual, higher the chances to develop certain limitations and comorbidities, including pain ${ }^{9,10}$. This instrument is the result of studies conducted by normative health agencies, such as the World Health Organization (WHO) and the desire to unify a questionnaire that could be useful in all world's populations to facilitate research ${ }^{11,12}$.

The IPAQ short version was used for the interviews. The reference used to evaluate PA was the previous week. Thus, a set of questions was asked related to the frequency and duration of moderate, vigorous $\mathrm{PA}$, and walking. The adopted evaluation system categorized the participants as very active; a) active; insufficiently active; b) insufficiently active, and sedentary.

For the data analysis, the volunteers who answered the IPAQ were classified into two categories: active - representing the participants who obtained results as "very active" or "active"; and insufficiently active - the population that obtained results as "insufficiently active a" and "insufficiently active b" at the PA level. The individuals classified as sedentary were excluded from the study because they represented a tiny sample in relation to the others.

The research was approved by the Ethics and Research Committee of UNIVASF (Opinion 1386029). All participants were aware of the research objectives and signed the Free and Informed Consent Term (FICT).

\section{Statistical analysis}

The data was processed in the Microsoft Excel software and analyzed using the Statistical Package for the Social Sciences (SPSS) 
Table 1. Anthropometric characteristics of the nursing professionals and nursing technicians of the study

\begin{tabular}{|c|c|c|c|c|c|c|}
\hline \multirow[t]{2}{*}{ Variables } & \multicolumn{3}{|c|}{ Gender } & \multicolumn{3}{|c|}{ Function } \\
\hline & Female & Male & $\mathrm{p}$-value & Nurse & Nursing technician & $\mathrm{p}$-value \\
\hline Age (years) & $37 \pm 7$ & $33 \pm 6$ & 0.028 & $34 \pm 7$ & $37 \pm 7$ & 0.031 \\
\hline Mass (kg) & $65.5 \pm 12.5$ & $80 \pm 15.6$ & $\leq 0.001$ & $66.5 \pm 14.9$ & $67.9 \pm 13.8$ & 0.631 \\
\hline Height (m) & $1.59 \pm 0.06$ & $1.71 \pm 0.07$ & $\leq 0.001$ & $1.62 \pm 0.07$ & $1.6 \pm 0.08$ & 0.311 \\
\hline Body mass index & $25.8 \pm 4.7$ & $27.1 \pm 4.3$ & 0.253 & $25 \pm 4.1$ & $26.2 \pm 4.8$ & 0.211 \\
\hline
\end{tabular}

p: Student's $t$-test.

program, version 22.0. The descriptive results were explored by the mean, standard deviation; absolute and relative frequencies. The Student's $t$-test was used for the comparison between the two groups. The prevalence ratios were used in the adjusted analysis, as a measure of association, estimated by the Poisson regression, with adjustment for a robust variance. Those that had a $\mathrm{p}<0.05$ were associated with the outcome studied.

\section{RESULTS}

The study population consisted of 374 nursing professionals. Of these, 143 professionals participated in the present study, being 26 nurses (18.2\%) and 117 nursing technicians (81.8\%). Of the total number of volunteers, $122(85.3 \%)$ were female, and 21 $(14.7 \%)$ were male. Table 1 shows the characteristics of the professionals evaluated.

Regarding the level of PA referred to in the IPAQ, according to the categorization adopted in the present study, 74 individuals $(51.8 \%)$ were classified as "active" and 69 (48.2\%) as "insufficiently active".

The pain was reported in 77 volunteers, equivalent to $53.8 \%$ of the sample. Of these, 15 are nurses (57.6\%), and 62 are nursing technicians (52.9\%). Overall, 35 (24.4\%) volunteers reported pain in more than one body segment. Table 2 shows the prevalence of pain by body segments. The MSD complaints were distributed as follows: lumbar region and knees $(17.4 \%)$ each; neck and shoulders (13.2\%) each; chest region (11.1\%); wrist and hand (9.7\%); ankle and foot (8.3\%); thigh $(7.6 \%)$ and elbow (2\%).

Table 3 shows the association between the pain outcome and the independent variables studied, with the adjusted values of the prevalence ratios obtained with the Poisson regression. The vari-

Table 2. Prevalence of pain per body segment in the nursing professionals of the study

\begin{tabular}{lcc}
\hline & \multicolumn{2}{c}{ Prevalence of pain } \\
Body segment & Absolute frequency & Relative frequency (\%) \\
\hline Lower back & 25 & 17.4 \\
Knees & 25 & 17.4 \\
Neck & 19 & 13.2 \\
Shoulders & 19 & 13.2 \\
Chest & 16 & 11.1 \\
Wrist and hand & 14 & 9.7 \\
Ankle and foot & 12 & 8.3 \\
Thigh & 11 & 7.6 \\
Elbow & 3 & 2.0 \\
\hline
\end{tabular}

Table 3. Poisson regression analysis with estimates of prevalence ratios and $95 \%$ confidence interval of the association between the presence of pain in each segment and the independent variables

\begin{tabular}{lll}
\hline $\begin{array}{l}\text { Body } \\
\text { segment }\end{array}$ & Independent variable & $\begin{array}{l}\text { Adjusted analysis - } \\
\text { PR Cl 95\% p-value }\end{array}$ \\
\hline Elbow & $\begin{array}{l}\text { Gender } \\
\text { Female } \\
\text { Male }\end{array}$ & $5.51 .0(1.1-25.5) 0.028$ \\
& $\begin{array}{l}\text { PA level } \\
\text { Active } \\
\text { Insufficiently active }\end{array}$ & $3.41 .0(1.1-10.3) 0.027$ \\
Knee & $\begin{array}{l}\text { PA level } \\
\text { Active } \\
\text { Insufficiently active }\end{array}$ & $2.41 .0(1.1-5.0) 0.021$ \\
Ankle & $\begin{array}{l}\text { Gender } \\
\text { Female } \\
\end{array}$ & \\
\hline Male & $5.11 .0(1.3-19.2) 0.016$ \\
\hline prevalence ratio PA = physical activity; $\mathrm{Cl}=$ confidence interval.
\end{tabular}

ables that remained in the final model were gender; function; PA level; mass; body mass index (BMI) and age. However, only the regressions that obtained statistically significant results $(\mathrm{p} \leq 0.05)$ are presented.

\section{DISCUSSION}

Low back pain was the most prevalent in this study, corroborating some findings in the literature ${ }^{13-15}$. Other body segments significantly affected were shoulders and cervical. This can be explained by the very nature of the work of the nursing team, responsible for most of the direct patient care. It is known that activities related directly to patients are often accompanied by static postures; anterior torso tilt and asymmetric lifting of loads; elements recognized in the literature as risk factors for the development of MSD in these regions ${ }^{13}$. Also, in a recent study with nurses in Pakistan, the identified factors that most contributed to the development of MSD were working in the same position for prolonged periods (93.1\%); working in tight spaces (78.6\%) and handling loads apart from the body $(64.1 \%)^{16}$.

In the present study, it was not possible to observe significant differences in pain regarding the professional profile. Nursing technicians had more physical and biomechanical risk factors that lead to MSD since they have more direct contact with patient demands, such as transfers, personal hygiene, among others ${ }^{16}$. On the other hand, nurses would be more exposed to psychosocial risk factors and cognitive demand, since they are the ones who perform most of the administrative functions of the sector ${ }^{17}$. Males had higher prevalence ratios for elbow pain $(\mathrm{PR}=5.5$, CI95\%:1.1, 25.5) and ankle (PR=5.1, CI95\%:1.3, 19.2) in 
relation to the females. In a survey with Australian nursing students, males had a higher prevalence of MSD than females. In this population, men were more involved in the manual handling of patients ${ }^{18}$, possibly exposing them to greater overloads in the elbow region. This may explain the higher occurrence of pain in this gender, and it is linked to anthropometric and cultural factors.

As for ankle pain, it is possible to say that both individual factors such as the type of footstep and the BMI, as well as work-related factors such as working hours and aspect of each sector, are relevant for complications ${ }^{19}$. Many of these factors were not analyzed in the present study. However, BMI did not show a significant difference between the genders.

Other relevant results in the present study were higher prevalence rates of elbow pain (PR:3.4 CI95\%:1.1-10.3) and knee (PR:2.4 CI95\%:1.1-5.0) in individuals who are insufficiently active in relation to the active ones.

A recent study ${ }^{20}$ found an association between decreased muscle strength and self-reported pain. Others have shown the beneficial effects of physical exercises to prevent or even reduce pain ${ }^{21-}$ ${ }^{25}$. In a clinical trial with industrial technicians in Denmark, upper limb muscles endurance was positively associated with the prevention and improvement of forearm pain. Physiological adaptations due to the forces exerted during the exercises, such as the increase in the synthesis of type I collagen in the eccentric phase of the movement may be associated with better work performance and lower association with $\mathrm{MSD}^{23}$.

Regarding the knee segment, a three-week aerobic exercise program showed a considerable increase in the percentage of $\mathrm{CD} 4^{+}$ $\mathrm{CD} 28^{+}$cell activation compared to the pre-intervention peri$\mathrm{od}^{24}$, thereby reducing the pain and inflammatory conditions triggered during work and daily activities ${ }^{25}$. However, other factors such as a history of injuries in other joints of the lower limbs and a varus alignment are of great importance in predicting the risk of MSD in this site ${ }^{26}$.

Regarding the limitations of the present study, one can highlight the self-report nature of the research instruments (NMQ and IPAQ, mainly), which makes it difficult to rule out the possibility of overestimation or underestimation bias. Another factor was the cross-sectional character of the study, where only associations should be made, not inferring any causality. In addition, there were no pain associations with aspects such as double work journey; working hours; daily activities; the practice of sports; among others, since they were not collected due to the characteristics of the research instruments and proposed objectives.

\section{CONCLUSION}

It can be noticed that in the sample of the evaluated professionals, the prevalence of musculoskeletal symptoms was high, suggesting a relationship between these symptoms and the activities performed by the nursing professionals. Moreover, some risk factors such as physical inactivity and being male were associated with increased pain.

\section{REFERENCES}

1. Lelis CM, Battaus MR, Freitas FC, Rocha FL, Marziale MH, Robazzi ML. Distúrbios osteomusculares relacionados ao trabalho em profissionais de enfermagem: revisăo integrativa da literatura. Acta Paul Enferm. 2012;25(3):477-82.

2. Magnago TS, de Lima AC, Prochnow A, Ceron MD, Tavares JP, Urbanetto Jde S. Intensity of musculoskeletal pain and (in) ability to work in nursing. Rev Lat Am Enfermagem. 2012;20(6):1125-33. English, Portuguese, Spanish.

3. De Souza Magnago TS, Lisboa MT, Griep RH, Kirchhof ALC, de Azevedo Guido L. Psychosocial aspects of work and musculoskeletal disorders in nursing workers. Rev Lat Am Enfermagem. 2010;18(3):429-35.

4. Harcombe H, Herbison GP, McBride D, Derrett S. Musculoskeletal disorders among nurses compared with two other occupational groups. Occup Med. 2014;64(8):601-7.

5. Ribeiro NF, Fernandes Rde C, Solla DJ, Santos Junior AC, de Sena Junior AS. [Prevalence of musculoskeletal disorders in nursing professionals]. Rev Bras Epidemiol. 2012;15(2):429-38. Portuguese.

6. Vieira MV, Alcântara DS. Prevalence of chronic low back pain in nursing: a bibliographic review. Rev Amazônia. 2013;1(3):49-55.

7. Pinheiro FA, Tróccoli BT, Carvalho CV. [Validity of the Nordic Musculoskeletal Question naire as morbidity measurement tool]. Rev Saude Publica. 2002;36(3):307-12. Portuguese.

8. Hugue TD, Pereira Júnior AA. Prevalência de dor osteomuscular entre os funcionários administrativos da Unifebe. Rev Unifebe. 2011;1(9):1-9.

9. Lima DM, Araújo RC, Pitangui AC, Rizzo JA, Sarinho SW, Santos CM, et al. Descrição da atividade física e da jornada de trabalho na qualidade de vida de profissionais de terapia intensiva: comparação entre um grande centro urbano e uma cidade do interior brasileiro. Rev Bras Ativ Fís Saúde. 2015;20(4):386-96.

10. Lopes JA, Longo GZ, Peres KG, Boing AF, de Arruda MP. [Factors associated with insufficient physical activity: a population-based study in southern Brazil]. Rev Bras Epidemiol. 2010;13(4):689-98. Portuguese.

11. Vespasiano BS, Dias R, Corrêa DA. Using the international of physical activity questionnaire (IPAQ) as a diagnostic tool in the level of physical fitness. Review in Brazil. Saúde Rev. 2012;12(32):49-54.

12. Garcia LM, Osti RF, Ribeiro EH, Florindo AA. Validaçâo de dois questionários para a avaliação da atividade física em adultos. Rev Bras Ativ Fís Saúde. 2013;18(3):317-8.

13. Fonseca Nda R, Fernandes Rde C. Factors related to musculoskeletal disorders in nursing workers. Rev Lat Am Enfermagem. 2010;18(6):1076-83.

14. Tinubu BM, Mbada CE, Oyeyemi AL, Fabunmi AA. Work-related musculoskeletal disorders among nurses in Ibadan, South-west Nigeria: a cross-sectional survey. BMC Musculoskelet Disord. 2010;11:12.

15. Freimann T, Coggon D, Merisalu E, Animägi L, Päsuke M. Risk factors for musculoskeletal pain amongst nurses in Estonia: a cross-sectional study. BMC Musculoskelet Disord. 2013;14:334.

16. Rathore FA, Attique R, Asmaa Y. Prevalence and perceptions of musculoskeletal disorders among hospital nurses in Pakistan: a cross-sectional survey. Cureus. 2017;9(1):e1001.

17. Moreira RF, Sato TO, Foltran FA, Silva LC, Coury HJ. Prevalence of musculoskeletal symptoms in hospital nurse technicians and licensed practical nurses: associations with demographic factors. Braz J Phys Ther. 2014;18(4):323-33.

18. Smith DR, Leggat PA. Musculoskeletal disorders among rural Australian nursing students. Aust J Rural Health. 2004;12(6):241-5.

19. Reed LF, Battistutta D, Young J, Newman B. Prevalence and risk factors for foot and ankle musculoskeletal disorders experienced by nurses. BMC Musculoskelet Disord. 2014:15:196.

20. Correa LQ, Rombaldi AJ, Silva MC. Physical activity level and self-reported musculoskeletal pain perception among older males. Rev Dor. 2016;17(3):183-7.

21. Sundstrup E, Jakobsen MD, Brandt M, Jay K, Aagaard P, Andersen LL. Strength training improves fatigue resistance and self-rated health in workers with chronic pain: a randomized controlled trial. Biomed Res Int. 2016;2016:4137918.

22. Sundstrup E, Jakobsen MD, Andersen CH, Jay K, Persson R, Aagaard P, et al. Effect of two contrasting interventions on upper limb chronic pain and disability: a randomized controlled trial. Pain Physician. 2014;17(2):145-54. Erratum in: Pain Physician. 2014;17(3):E275.

23. Andersen LL, Jakobsen MD, Pedersen MT, Mortensen OS, Sjøgaard G, Zebis MK. Effect of specific resistance training on forearm pain and work disability in industrial technicians: cluster randomised controlled Trial. BMJ Open. 2012;2(1):e000412.

24. Freitas DA, Guedes MB, Fonseca SF, Amorim MR, Gomes WF, Melo GE, et al. Efeito de um programa de treinamento aeróbio na dor, desempenho físico e funcional e na resposta inflamatória em idosos com osteoartrite de joelho-resultados preliminares. Rev Ter Man. 2012;10(47):52-9

25. Dobson JL, McMillan J, Li L. Benefits of exercise intervention in reducing neuropathic pain. Front Cell Neurosci. 2014;8(1):102.

26. Fernandes GS, Bhattacharya A, McWilliams DF, Ingham SL, Doherty M, Zhang W. Risk prediction model for knee pain in the Nottingham community: a Bayesian modelling approach. Arthritis Res Ther. 2017;19(1):59. 